\title{
Anatomical Study of Periosteal Vascularization of the Forearm: Design of Vascularized Periosteal Flaps
}

\section{Estudio anatómico de la vascularización perióstica del antebrazo: diseño de colgajos vascularizados periósticos}

\author{
Sergi Barrera-Ochoa ${ }^{1,2}$ David Campillo-Recio ${ }^{2}$ Jorge Knorr ${ }^{1}$ Xavier Mir-Bullo ${ }^{2}$ \\ Alfonso Rodríguez-Baeza ${ }^{3}$ Francisco Soldado ${ }^{1}$ \\ ${ }^{1}$ Hospital Sant Joan de Déu, Barcelona, Spain \\ 2 Institut Català de Traumatologia i Medicina de l'Esport (ICATME). \\ Barcelona, Spain \\ ${ }^{3}$ Departamento de Embriología y Anatomía Humana, Universidad \\ Autónoma de Barcelona. Barcelona, Spain \\ Address for correspondence Sergi Barrera-Ochoa, MD, PhD, \\ Hospital Sant Joan de Déu, Barcelona, Spain \\ (e-mail: dr.barreraochoa@gmail.com). \\ Rev Iberam Cir Mano 2018;46:106-112.
}

\begin{abstract}
Introduction Vascularized periosteal flaps (VPFs) have proven to be a useful technique for the treatment of unfavorable biological situations in children, with excellent results due to their osteogenic potential. The objective of this work is to present a detailed anatomical description of the periosteal vascularization of the radius and ulna, as well as the design of the forearm VPFs.

Methods Anatomical study with 10 fresh-frozen specimens with antegrade injection of green colored latex. Periosteal branches of the radius and ulna, septocutaneous branches, and muscular branches were dissected. The size of the pre and postdissection flaps was measured, as well as the length of the vascular pedicles.

Results The four vascular axes studied were the anterior interosseous vascular axis (AIA), radial axis (RA), ulnar axis (UA), and posterior interosseous vascular axis (PIA). The AIA (volar-radial VPF): an average of 16.2 periosteal branches were obtained, with a mean distance of $6.6 \mathrm{~mm}$ between them. The mean size of the VPF was $41.3 \mathrm{~cm}^{2}$ predissection and $32.4 \mathrm{~cm}^{2}$ post-dissection. The average pedicle length was $16.1 \mathrm{~cm}$. Vascular RA (radial VPF): an average of 20.8 branches was found, with a mean VPF size of $54.8 \mathrm{~cm}^{2}$ predissection, and $39.3 \mathrm{~cm}^{2}$ post-dissection. The average pedicle length was $20.2 \mathrm{~cm}$. Vascular PIA (dorsal-ulnar VPF): an average of 12.8 periosteal branches were obtained, with the mean VPF size being $26.2 \mathrm{~cm}^{2}$ pre-dissection and $20.4 \mathrm{~cm}^{2}$ post-dissection. The average pedicle length $12.6 \mathrm{~cm}$. Vascular UA (ulnar VPF): an

Keywords

- vascularized periosteal flap

- periosteum

- anatomical study

- anatomy

- pseudoarthrosis

- forearm average of 10.2 periosteal branches were obtained with a mean VPF size of $37.5 \mathrm{~cm}^{2}$ pre-dissection and $28.2 \mathrm{~cm}^{2}$ post-dissection. of the average pedicle length was $14.8 \mathrm{~cm}$.

Conclusions We have described four new VPFs, with the most useful and versatile being the dorsal-ulnar VPF, based on the PIA, and the volar-radial, based on the AIA. The main advantages of these flaps with respect to microsurgical techniques are the simplicity and speed of the technique, its elasticity and adaptability to the recipient bed, as well as its versatility.
\end{abstract}

received

May 25, 2018

accepted

October 10, 2018
DOI https://doi.org/

$10.1055 / \mathrm{s}-0038-1676083$. ISSN $1698-8396$.
Copyright $\odot 2018$ Thieme Revinter

Publicações Ltda, Rio de Janeiro, Brazil
License terms

(c) $(1) \$$ 


\section{Resumen}

\author{
Palabras clave \\ - colgajo perióstico \\ vascularizado \\ - periostio \\ - estudio anatómico \\ - anatomía \\ - pseudoartrosis \\ - antebrazo
}

Introducción Los colgajos vascularizados periósticos (CVP) han demostrado ser una técnica útil para el tratamiento de situaciones biológicas desfavorables en población infantil con excelentes resultados debido a su potencial osteogénico. El objetivo de este trabajo es presentar una descripción anatómica detallada de la vascularización perióstica del radio y cúbito, así como el diseño de CVP de antebrazo.

Material y método Estudio anatómico con 10 especímenes frescos congelados inyectados de forma anterógrada en látex verde coloreado. Se disecaron ramas periósticas para el radio y ulna, ramas septo-cutáneas y ramas musculares. Se midió el tamaño de los colgajos pre y post-disección, así como la longitud de los pedículos vasculares.

Resultados Los 4 ejes vasculares estudiados fueron el eje vascular interóseo anterior (AIA), radial (AR), ulnar (AU), e interóseo posterior (AIP). Eje vascular AIA (CVP volarradial): se obtuvieron una media de 16,2 ramas periósticas, con una media de $6,6 \mathrm{~mm}$ de distancia entre ellas siendo el tamaño medio del CVP de $41,3 \mathrm{~cm}^{2}$ antes de la disección y de $32,4 \mathrm{~cm}^{2}$ post-disección. Longitud media de pedículo $16,1 \mathrm{~cm}$. Eje vascular AR (CVP radial): la media de ramas periósticas fue de 20,8 ramas con un tamaño medio CVP pre-disección fue de $54,8 \mathrm{~cm}^{2}$ y $39,3 \mathrm{~cm}^{2}$ post-disección. Longitud media del pedículo $20,2 \mathrm{~cm}$. Eje vascular AIP (CVP dorso-ulnar): se obtuvieron una media de 12,8 ramas periósticas siendo el tamaño medio del CVP de $26,2 \mathrm{~cm}^{2}$ predisección y $20,4 \mathrm{~cm}^{2}$ post-disección con una longitud media de pedículo de $12,6 \mathrm{~cm}$. Eje vascular AU (CVP ulnar): la media fue de 10,2 ramas periósticas con un tamaño medio del CVP pre-disección de $37,5 \mathrm{~cm} 2$ years $28,2 \mathrm{~cm} 2$ post-disección y un pedículo de $14,8 \mathrm{~cm}$.

Conclusiones Hemos descrito 4 nuevos CVP siendo los más útiles y versátiles el CVP dorso-ulnar basado en la AIP y el volar-radial basado en la AIA. Las principales ventajas de estos colgajos con respecto a las técnicas microquirúrgicas son la sencillez y rapidez de la técnica, su elasticidad y adaptabilidad al lecho receptor, así como su versatilidad.

\section{Introduction}

Recently, the use of vascularized periosteal flaps (VPFs) has been reported in the treatment of unfavorable situations in the pediatric population, such as recalcitrant pseudarthrosis, avascular necrosis or massive bone defects. These VPFs have demonstrated their high osteogenic potential with high capacity to revascularize and integrate autologous and even heterologous bone. ${ }^{1-3}$

These osteogenic properties derive from the presence of stem cells in the cambium layer, ${ }^{2,4-6}$ which become osteoblasts responsible for the increase in the diameter of the bone axis by intramembranous ossification. However, after a bone fracture, the progenitor cells turn into osteoblasts and chondroblasts and promote bone healing through an endochondral process.

This means that these VPFs present excellent results in bone consolidation rates, speed of consolidation and revascularization. In addition, these VPFs are technically less demanding, faster to extract, and their elasticity allows them to easily adjust to the recipient bed.

Some examples of VPFs are the fibular VPF (based on the peroneal vessels), the tibial VPF (based on the anterior tibial vessels) or the first metatarsal VPF (based on the dorsal branches of the dorsalis pedis artery). ${ }^{2,3}$

The objective of this work is to present a detailed anatomical description of the periosteal vascularization of the radius and ulna, and the design of the VPF based on the radial (RA), ulnar (UA), anterior interosseous (AIA), and posterior interosseous (PIA) axes.

\section{Methods}

The present study was performed in the Department of Human Anatomy and Embryology of the Universidad Autónoma de Barcelona. Ten fresh-frozen specimens (five left and five right) injected in colored green latex were used in anterograde form from the brachial artery at the elbow. Results: the four vascular axes studied were the AIA, the RA, the UA, and the PIA. A volar approach was performed for the AIA, RA and UA vascular axes, and the dorsal approach was used for the vascular axis of the PIA. With a magnifying glass view of $2.5 \mathrm{x}$ magnification, the periosteal, septocutaneous and muscular branches of the radius and ulna were dissected. The size of the pre and post-dissection flaps was 
measured, considering the major and minor axes of the retracted flap surface after extraction, not including the pedicle. In all cases, an attempt was made to obtain the largest flap possible by including the maximum number of periosteal branches. The length of the vascular pedicles was also measured, defining said pedicle as the length of the vessel not included in the vascularized flap. Three different measurements were made by three different people, finally obtaining the arithmetic mean of the three measurements. All measurements were made with Mitutoyo Digital Series calipers $500 \times 77$ (Mitutoyo, Kawasaki, Kanagawa, Japan).

\section{Results}

The results of the anatomical study are summarized in - Table 1 .

Vascular AIA (VPF volar-radial) (-Fig. 1): an average of 16.2 periosteal branches were observed (14-18), with an average of $0.66 \mathrm{~cm}$ distance between them (0.2-1.7), with 7.7 septocutaneous branches (6-10) and 18.1 muscle branches (range 14 to 20 ). Of these muscle branches, 7.5 provided vascularity for the pronator quadratus (range 5-10) and 11.2 for the flexor digitorum profundus (range 8-13). The mean size of the VPF was $41.3 \mathrm{~cm}^{2}$ before dissection and $32.4 \mathrm{~cm}^{2}$ post-dissection with a mean pedicle length of $16.1 \mathrm{~cm}$ (range $13.9 \mathrm{~cm}-18.8 \mathrm{~cm})$.

Vascular RA (VPF radial): the average of the periosteal branches was 20.8 branches (18-23), with $0.81 \mathrm{~cm}$ average distance between them (0.4-1.6), and 12 septocutaneous branches (8-12). The mean VPF size was $54.8 \mathrm{~cm}^{2}$ predissection, and $39.3 \mathrm{~cm}^{2}$ post-dissection. The average length of the pedicle was $20.2 \mathrm{~cm}$ (range $19.9 \mathrm{~cm}-22.7 \mathrm{~cm}$ ).

Vascular PIA (VPF dorsal-ulnar) (-Fig. 2): an average of 12.8 periosteal branches were obtained (11-14), with a mean distance of $0.96 \mathrm{~cm}$ between them (range 0.2-2.5), of which 7.7 periosteal branches are medial (60\%) and 5 are lateral (40\%). The average number of septocutaneous

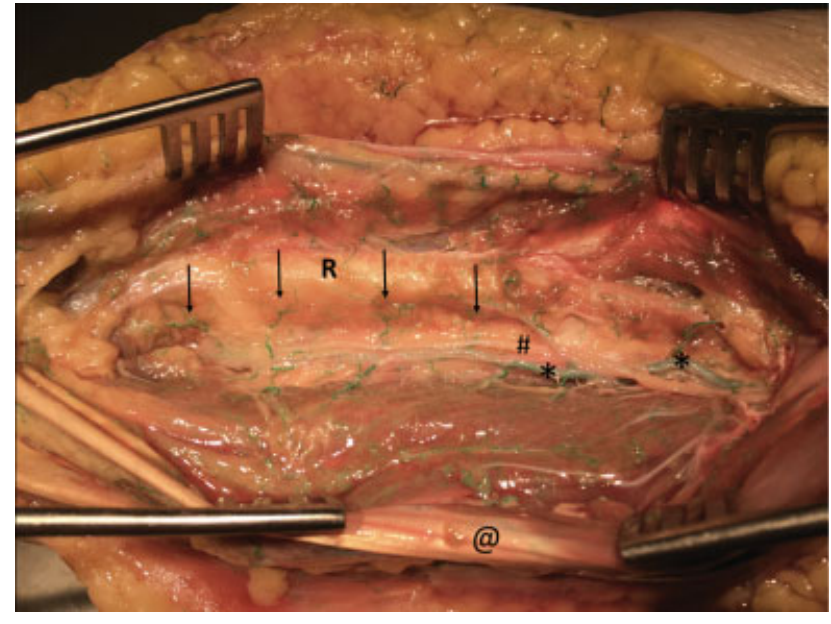

Fig. 1 Anterior compartment of the forearm. * Anterior interosseous artery (AIA) with its periosteal branches. @ Flexor digitorum superficialis. R: Radius. \# Anterior interosseous nerve in its radial course with respect to the AIA.

branches is 7.3 (range 6-10) and 13.1 of muscle branches (range 10-15) (7.5 for the extensor digiti minimi (range 5-10) and 5.5 for the extensor carpis ulnaris (range 4-8). The VPF average was $26.2 \mathrm{~cm}^{2}$ pre-dissection and $20.4 \mathrm{~cm}^{2}$ postdissection. The average pedicle length was $12.6 \mathrm{~cm}$ (range $10.2 \mathrm{~cm}-14.5 \mathrm{~cm}$ ).

Vascular UA (VPF ulnar): in this case the average was 10.2 periosteal branches (8-12) with $1.15 \mathrm{~cm}$ average distance between them (0.4-1.6) and 8 septocutaneous branches (812). The mean size of the VPF was $37.5 \mathrm{~cm}^{2}$ pre-dissection and $28.2 \mathrm{~cm}^{2}$ post-dissection, with an average pedicle length of $14.8 \mathrm{~cm}$ (range $13.6 \mathrm{~cm}-16.3 \mathrm{~cm}$ ).

The width of all periosteal branches in the 4 vascular axes was less than $1 \mathrm{~mm}$.

Table 1 Summary of obtained descriptive data in the anatomic study

\begin{tabular}{|c|c|c|c|c|}
\hline \multicolumn{5}{|l|}{ Anatomic study summary } \\
\hline & $\begin{array}{l}\text { AIA } \\
\text { (Volar-Radial Flap) }\end{array}$ & $\begin{array}{l}\text { AR } \\
\text { (Radial Flap) }\end{array}$ & $\begin{array}{l}\text { AIP } \\
\text { (Dorsal-Ulnar Flap) }\end{array}$ & $\begin{array}{l}\text { AC } \\
\text { (Cubital Flap) }\end{array}$ \\
\hline $\begin{array}{l}\text { Average Periosteal } \\
\text { branches (range) }\end{array}$ & $16.2(14-18)$ & $20.8(18-23)$ & $12.8(11-14)$ & $10.2(8-12)$ \\
\hline Average distance (range) & 0.66 cm $(0.2-1.7)$ & $0.81 \mathrm{~cm}(0.4-1.6)$ & 0.96 mm (0.2-2.5) & $1.5 \mathrm{~cm}(0.4-1.6)$ \\
\hline $\begin{array}{l}\text { Septocutaneous } \\
\text { branches (range) }\end{array}$ & $7.7(6-10)$ & $12(8-12)$ & $7.3(6-10)$ & $8(8-12)$ \\
\hline Muscular branches (range) & $18.1(14-20)$ & & $13.1(10-15)$ & \\
\hline \multirow{2}{*}{$\begin{array}{l}\text { muscular branches average } \\
\text { distribution (range) }\end{array}$} & PQ $7.5(5-10)$ & \multirow[t]{2}{*}{-} & EDM $7.5(5-10)$ & \multirow[t]{2}{*}{-} \\
\hline & FDP $11.2(8-13)$ & & ECU $5.5(4-8)$ & \\
\hline VPF mean size pre- dissection & $41.3 \mathrm{~cm}^{2}$ & $54.8 \mathrm{~cm}^{2}$ & $26.2 \mathrm{~cm}^{2}$ & $37.5 \mathrm{~cm}^{2}$ \\
\hline VPF mean size post-dissection & $32.4 \mathrm{~cm}^{2}$ & $39.3 \mathrm{~cm}^{2}$ & $20.4 \mathrm{~cm}^{2}$ & $28.2 \mathrm{~cm}^{2}$ \\
\hline average pedicle length (range) & $16.1 \mathrm{~cm}(13.9-18.8)$ & 20.2 cm (19.9-22.7) & $12.6 \mathrm{~cm}(10.2-14.5)$ & $14.8 \mathrm{~cm}(13.6-16.3)$ \\
\hline
\end{tabular}

Abbreviations: AIA, anterior interosseous axis; AIP, posterior interosseous axis; RA, radial axis; CA, cubital artery; ECU, extensor carpis ulnaris; EDM, extensor digiti minimi; FDP, flexor digitorum profundus; PQ, pronator quadratus. 


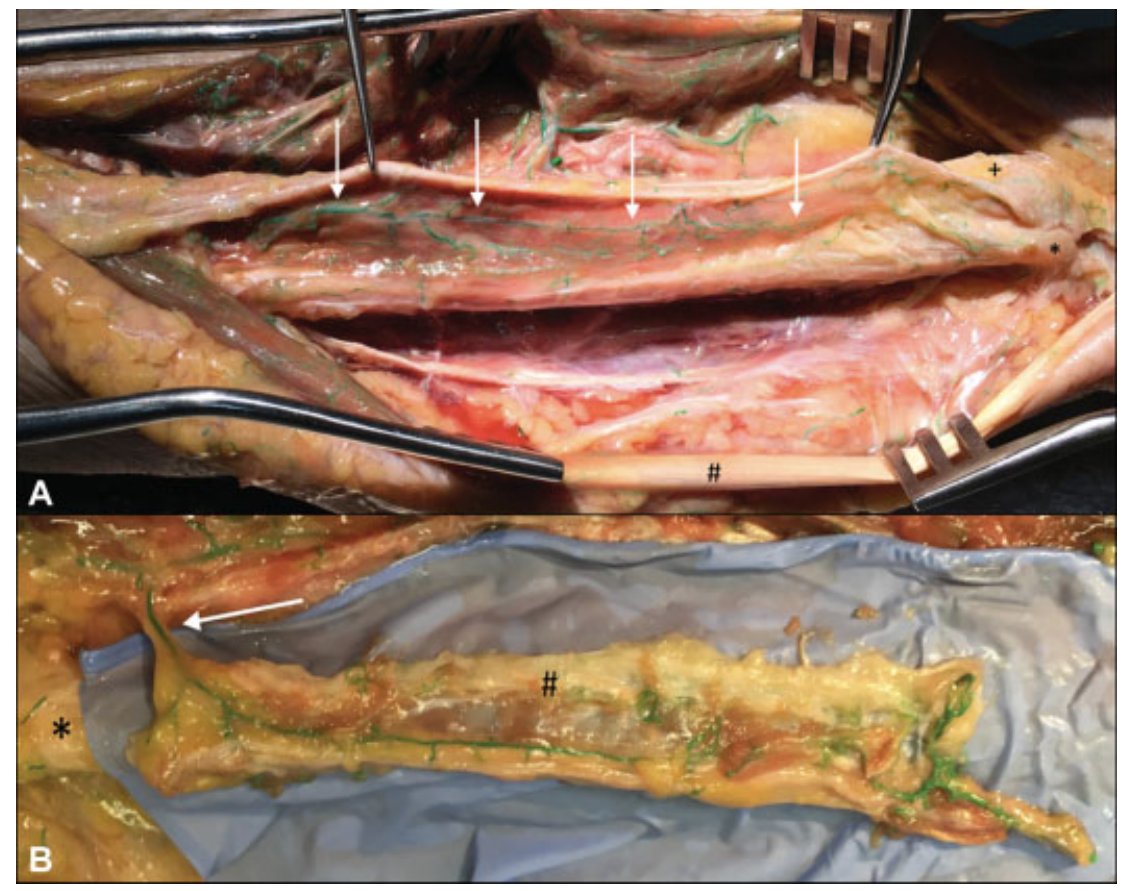

Fig. 2 Vascularized periosteal flap (VPF) dorsal-ulnar (vascular posterior interosseous artery-axis). A: + ulnar head; * Ulnar styloids; \# Extender carpis ulnaris; white arrows-periosteal branches of the posterior interosseous artery (PIA). B: Example of dissection of a dorsal-ulnar vascularized periosteal flap based on the PIA (white arrow). The length and width of the flap are visible.

\section{Clinical Applicability}

Case 1: A 6-year-old female patient with a history of open radial diaphysis fracture (Gustilo I) and treated with internal fixation using intramedullary titanium elastic nail system (TENS). The patient developed atrophic pseudarthrosis; thus, we performed a VPF based on the PIA without replacing the
TENS and without adding bone graft in the focus of the pseudarthrosis, achieving complete consolidation at 6 months (-Figs. 3 and $\mathbf{4}$ ).

Case 2: A 26-year-old male patient operated on two occasions for arthrodesis of the carpometacarpal $-4^{\text {th }}$ and $5^{\text {th }}$ metacarpal base without success. A retrograde PIA ulnar

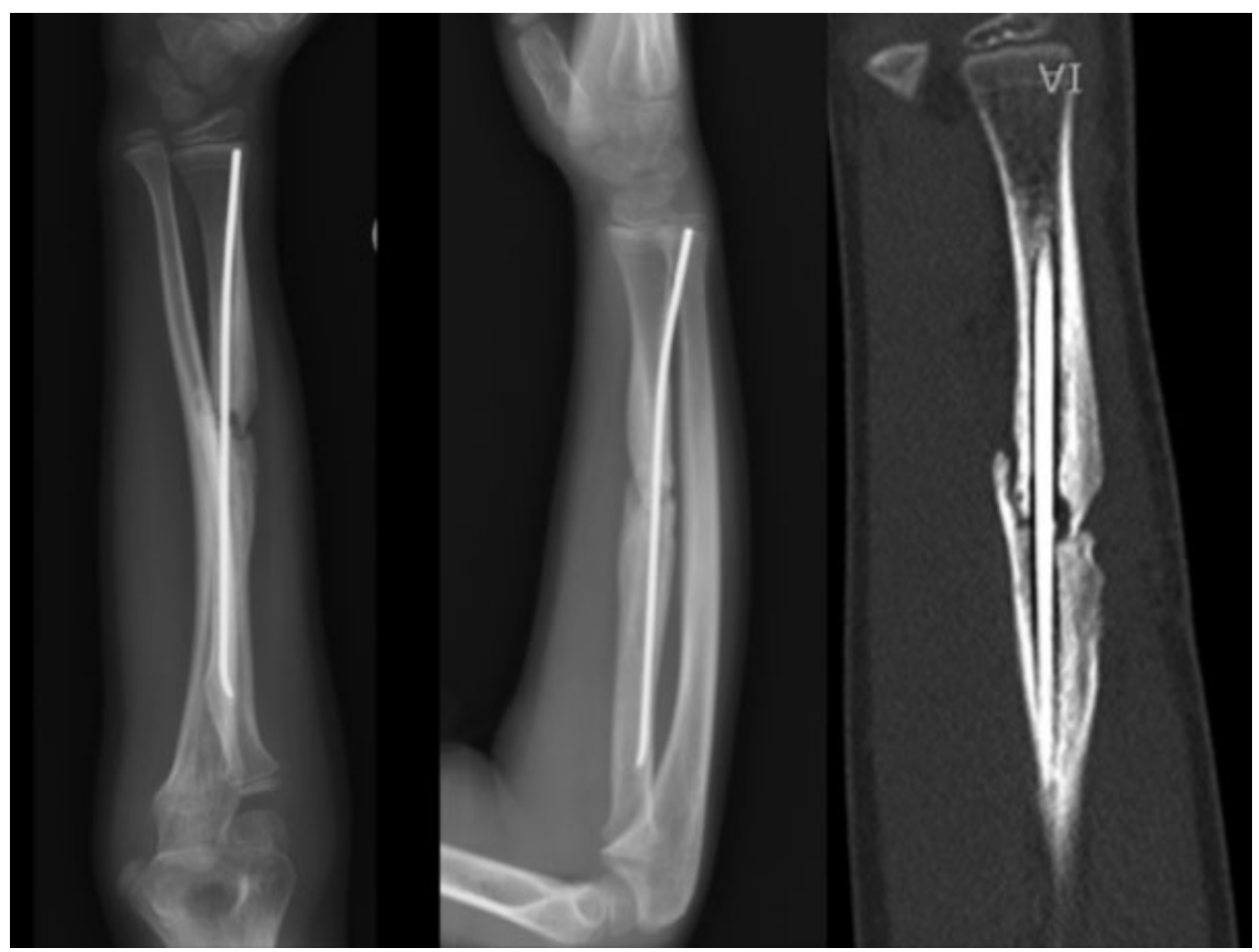

Fig. 3 Case 1. Rx and CT of the forearm of 6-year-old girl with atrophic pseudarthrosis of radius secondary to open fracture (Gustilo I) treated by internal fixation with titanium elastic nail system (TENS). 

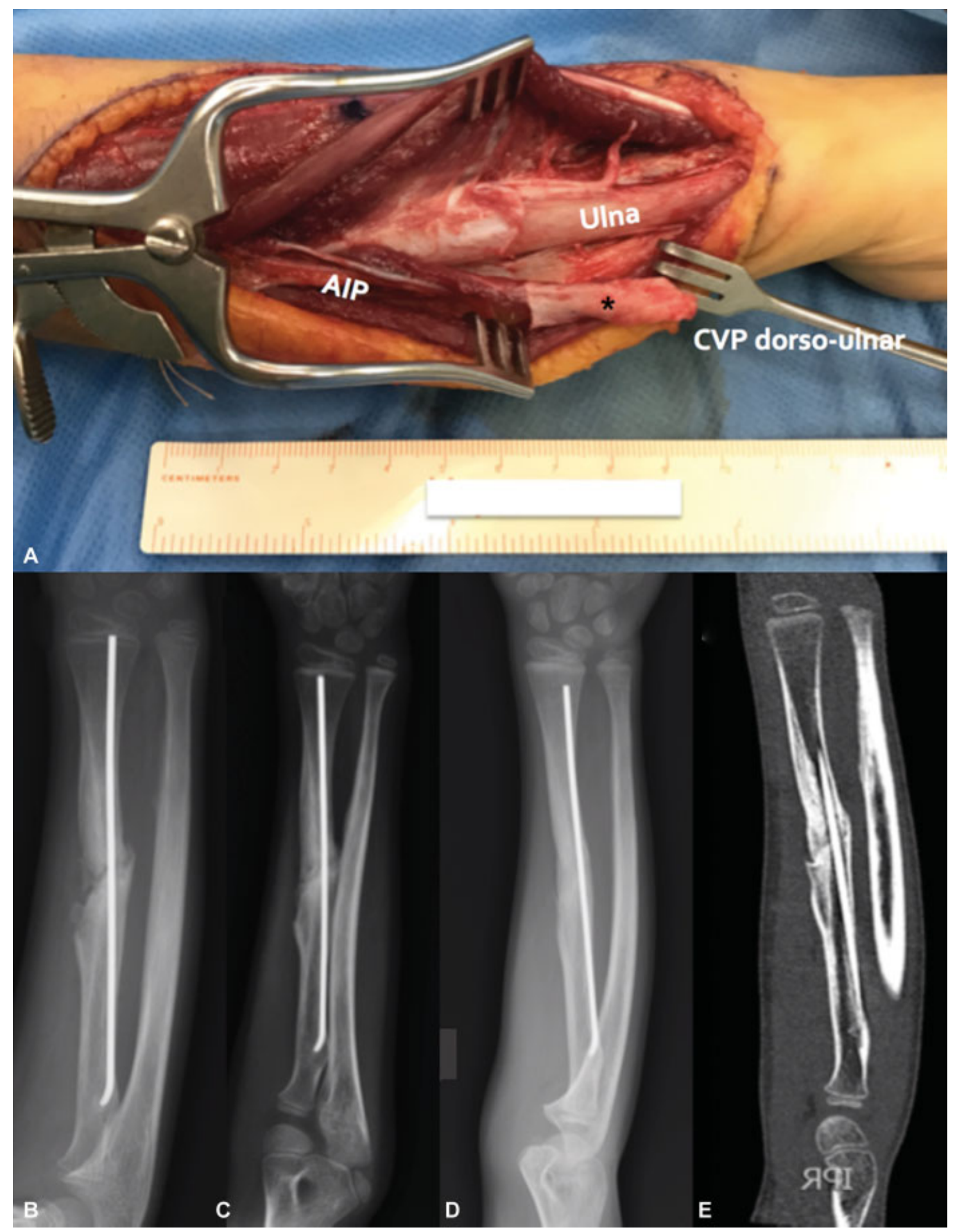

Fig. 4 Case 1. A: Vascularized periosteal flap (VPF) of the posterior interosseous artery (PIA) in a 6-year-old male patient with atrophic pseudarthrosis of the radius. B: Radiological evolution at one month of follow-up. C: Radiological evolution at 2 months of follow-up. D: Rx at 6 months of follow-up with full consolidation. E: Forearm computed tomography (CT) scan at 6 months of follow-up, with full consolidation.

VPF was performed, achieving complete consolidation after 3 months of follow-up (-Fig. 5).

\section{Discussion}

Despite the description in the literature of multiple options for treatment in unfavorable clinical situations, such as recalcitrant pseudarthrosis, avascular necrosis or bone defects, there are no definitive clinical guidelines for the treatment of this type of patient. One of the most accepted treatments is the use of vascularized bone grafts. ${ }^{7}$ However, they are very complex microsurgical techniques.

The complexity of the microsurgical techniques associated with the high osteogenic potential demonstrated by the 


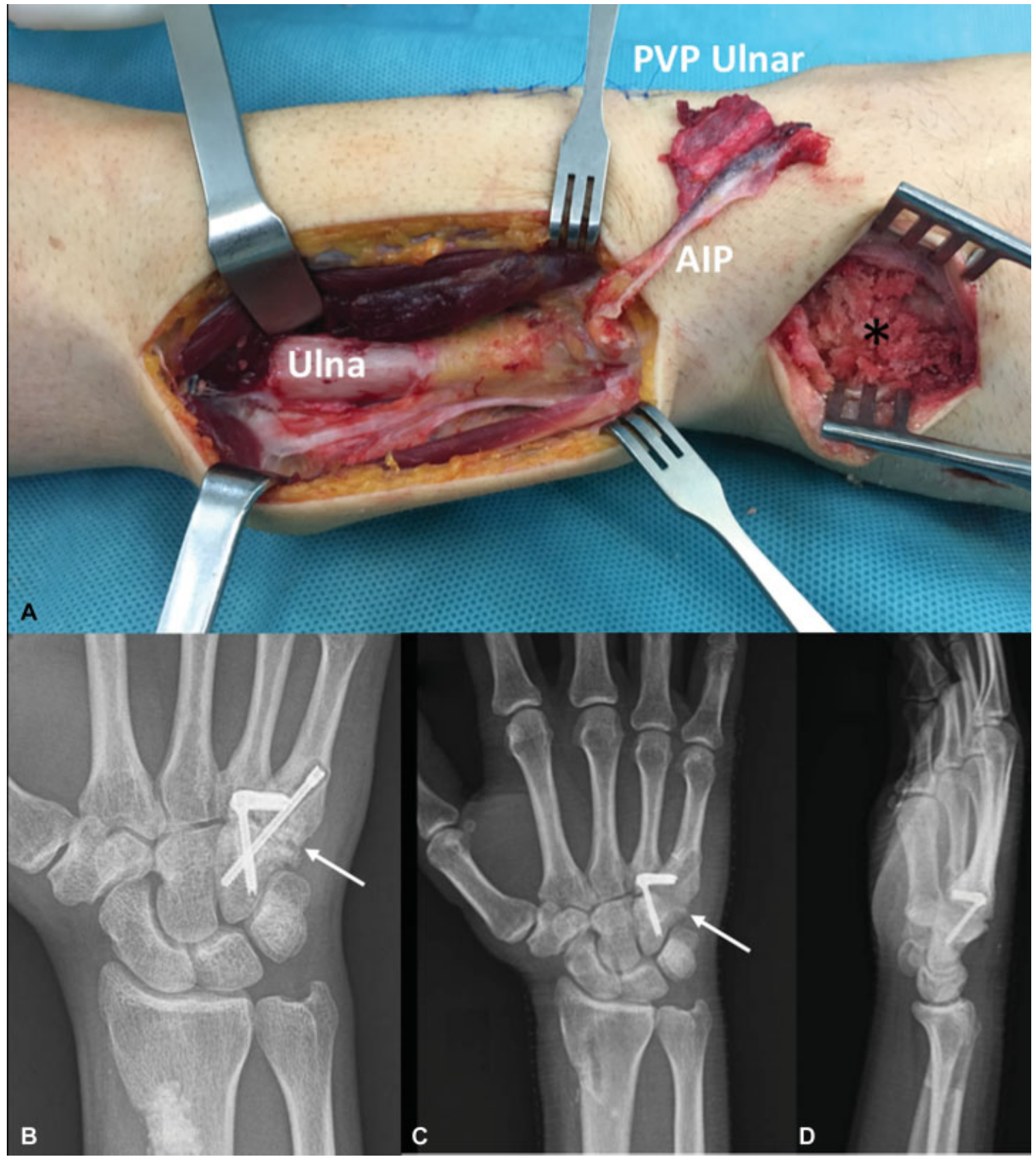

Fig. 5 Case 2. A 26-year-old male patient operated on two occasions of arthrodesis of the carpometacarpal- $4^{\text {th }}$ and $5^{\text {th }}$ metacarpal base without success. A: Vascularized periosteal flap (VPF) of retrograde posterior interosseous artery (PIA). * Area of pseudarthrosis. B: Presurgical anteroposterior Rx with carpometacarpal pseudarthrosis. C and D: Anteroposterior Rx and postsurgical profile showing complete consolidation of the pseudarthrosis at 3 months of follow-up.

$\mathrm{VPF}^{1-3}$ has increased the use of VPF in unfavorable biological situations. $^{2-4}$

The high osteogenic potential of the VPF, and its consequent efficacy promoting a faster consolidation with respect to vascularized bone grafts, ${ }^{8,9}$ is due to the abundant number of stem cells with osteogenic potential present in the cambium $^{2,4-6}$ layer.

One of these VPFs (dependent on the vascular PIA), was previously described by our group for the treatment of patients with radius nonunion and associated bone defect. ${ }^{10}$ In the present study, we made a detailed description of the periosteal vascularization of the forearm, adding to the previous study 3 new VPFs, namely the RA, UA and AIA.

In an anatomical study performed with 25 fresh specimens, ${ }^{11}$ Penteado considers the distal third of the humerus and femur as the donor areas of choice for the extraction of VPF. However, in the present study, unlike the results published by Penteado, we have observed an important periosteal vascular network in the forearm, with an average of 15 periosteal branches, of which the radial VPF is the most vascularized one, with an average of 20.8 periosteal branches. 
Furthermore, in view of the results obtained in the clinical cases presented as well as what is described in the literature, these VPFs avoid the need for bone supply due to their high osteogenic potential per $s e^{2,4-6,12}$

Another advantage of VPFs with respect to microsurgical techniques is the ease and speed of harvesting the flap, as well as its elasticity, which allows greater adaptability to the recipient side. This elasticity explains the elastic retraction in the size of the post-dissection flap when compared with the pre-dissection size. ${ }^{8,13-16}$ In addition, unlike the microsurgical procedures, the VPF described decreases the morbidity of the donor areas.

On the other hand, the great versatility offered by these four new VPFs described is remarkable, since they can be designed retrograde and antegrade, based on their vascular axes, as well as chimera due to the large number of periosteal cutaneous branches or periosteal muscle branches. In this sense, ulnar and radial flaps have the largest number of septocutaneous branches present throughout their course. In PIA-dependent flaps, the septocutaneous branches are located preferably at the junction between the proximal third and the distal third, with the AIA-dependent flap with the fewest septocutaneous branches, located preferably in the proximal area.

We have observed, based on the number of periosteal branches, the absence of sacrifice of main vascular axes and ease of dissection, that the most versatile and useful VPFs in the forearm are the dorsal-VPFs, based on the PIA, and the volar-radial VPFs, based on the AIA.

In relation to the applicability of VPFs, these are pediatric flaps, which can only be used in adolescents and young adults, due to age-related decrease in osteogenic capacity. ${ }^{2}$

\section{Conclusions}

Vascularized periosteal flaps represent a viable alternative in unfavorable biological situations due to their high osteogenic potential. The main advantages of these flaps are the simplicity and speed of the technique, their elasticity and adaptability to the recipient bed, as well as their versatility, as they can be designed as antegrade, retrograde and chimeric. We have described four new VPFs, as well as their clinical application, with the most versatile and useful ones being the dorsal-ulnar VPF, based on the PIA, and the volar-radial VPF, based on the AIA.

\section{References}

1 Qi B, Yu A, Zhang G, et al. The treatment of displaced femoral neck fractures with vascularized great trochanter periosteal flap transposition in children. Microsurgery 2008;28(01):21-24

2 Soldado F, Fontecha CG, Barber I, et al. Vascularized fibular periosteal graft: a new technique to enhance bone union in children. J Pediatr Orthop 2012;32(03):308-313

3 Soldado F, Knörr J, Haddad S, et al. Vascularized tibial periosteal graft in complex cases of bone nonunion in children. Microsurgery 2015;35(03):239-243

4 Soldado F, Diaz-Gallardo P, Sena-Cabo L, et al. Vascularized fibular grafts extended with vascularized periosteum in children. Microsurgery 2017;37(05):410-415

5 Soldado F, Garcia Fontecha C, Haddad S, Hernandez-Fernandez A, Corona P, Guerra-Farfan E. Treatment of congenital pseudarthrosis of the tibia with vascularized fibular periosteal transplant. Microsurgery 2012;32(05):397-400

6 Finley JM, Wood MB, Acland RD. Osteogenesis from periosteal autografts in ulnar defects in dogs. J Microsurg 1979;1(03):203-207

7 Mathoulin C, Gilbert A, Azze RG. Congenital pseudarthrosis of the forearm: treatment of six cases with vascularized fibular graft and a review of the literature. Microsurgery 1993;14(04):252-259

8 Kamrani RS, Mehrpour SR, Sorbi R, Aghamirsalim M, Farhadi L. Treatment of nonunion of the forearm bones with posterior interosseous bone flap. J Orthop Sci 2013;18(04):563-568

9 Cheema TA, Lakshman S, Cheema MA, Durrani SF. Reverse-flow posterior interosseous flap-a review of 68 cases. Hand (N Y) 2007; 2(03):112-116

10 Barrera-Ochoa S, Velez R, Rodriguez-Baeza A, De Bergua-Domingo JM, Knörr J, Soldado F. Vascularized ulnar periosteal pedicled flap for forearm reconstruction: Anatomical study and a case report. Microsurgery 2017

11 Penteado CV, Masquelet AC, Romana MC, Chevrel JP. Periosteal flaps: anatomical bases of sites of elevation. Surg Radiol Anat 1990;12(01):3-7

12 Diaz-Gallardo P, Knörr J, Vega-Encina I, et al. Free vascularized tibial periosteal graft with monitoring skin island for limb reconstruction: Anatomical study and case report. Microsurgery 2017; 37(03):248-251

13 Akin S, Ozgenel Y, Ozcan M. Osteocutaneous posterior interosseous flap for reconstruction of the metacarpal bone and soft-tissue defects in the hand. Plast Reconstr Surg 2002;109(03):982-987

14 Andro C, Richou J, Schiele P, Hu W, Le Nen D. Radius graft pedicled on the anterior interosseous artery for recurrent ulnar nonunion. Orthop Traumatol Surg Res 2011;97(4, Suppl):S12-S15

15 Pagnotta A, Taglieri E, Molayem I, Sadun R. Posterior interosseous artery distal radius graft for ulnar nonunion treatment. J Hand Surg Am 2012;37(12):2605-2610

16 Shahryar Kamrani R, Farhoud AR, Nabian MH, Farhadi L. Treatment of Nonunion of Forearm Bones Using Radial Forearm Bone Flap. Trauma Mon 2015;20(04):e22622 